\title{
Zakat and Accounting Valuation Model
}

\author{
Essia Ries Ahmed ${ }^{1, *}$, Ku Halim Bin Aiffin ${ }^{1}$, Tariq Tawfeeq Yousif Alabdullah ${ }^{2}$ and \\ Ahmed Zuqebah ${ }^{3}$
}

${ }^{1}$ Universiti Malaysia Perlis (UniMap), School of Business Innovation \& Technopreneurship, Perlis, Malaysia

${ }^{2}$ University of Basrah, College of Administration and Economics, Iraq

${ }^{3}$ Universiti Sains Malaysia, School of Management, 11800 USM, Pulau Pinang, Malaysia

\begin{abstract}
The valuation and measurement of assets with regard to Zakat is necessary issue from Islamic perspective. Therefore, re-value the assets regularly is needed and Islamic accounting system probably uses both historical and market selling prices with regard to enable firms to accommodate contracts and to discharge with social responsibility. Zakat accounting includes the accounting principles that relate not only to measurement and valuation but also recording, interpreting, presentation and disclosure of accounting information. Thus, the main objective of this paper is to elaborate the importance of Islamic accounting valuation adopted in zakat regard to accounting models. The application and mechanics of zakat and valuation model discussed related to the implementation of the current practices of accounting and valuation models that adopted in Islamic firms.
\end{abstract}

Keywords: Zakat, Valuation, Accounting Models, Shariah.

\section{INTRODUCTION}

Accounting and valuation of zakat is an important aspect of any business activities and investment and this is centred on the fact that it helps to determine the zakat payment (Ismail, Tohirin, \& Ahmad, 2015). The availability of various corporate zakat assessment approaches shows that zakat is subject to variation and change (Ammani, Abba, \& Dandago, 2014; Ahmad, \& Marhaini, 2012). Islam allows considerable flexibility in using reason to solve new challenging's (Firdaus, et al., 2012). In the case of zakat, ijtihad could be necessary elements to devise new regulations to deal with new situations (Sarif, 2014 \& Bakar, 2007). ljtihad refers to a jurist's use of reasoning to find solutions to new problems, keeping in view Islam's intent and spirit. Methods of ijtihad include qiyas, istihsan, and istislah (Khan, \& Ramadan, 2011). Among the prime prerequisites of developing new zakat principles is that they benefit the general public, avoid harm, serve the maqasid al-Shariah which refers to the preservation of five rights, namely, religion, life, intellect, lineage, and wealth and provide justice to the majority (Abdullah, \& Muhammad, 2013). Thus, given that Islam allows variation in zakat affairs based on time and place. Thus, this paper seeks to understand and illustrate Islamic accounting valuation adopted in Islamic firms as it related to shariah compliant. In line with the study objective, this paper will seek to determine zakat and valuation model.

\footnotetext{
*Address correspondence to this author at the Universiti Malaysia Perlis (UniMap), School of Business Innovation \& Technopreneurship, Perlis, Malaysia; Tel: 04-9797704; Fax: 04-9797708;

E-mail: essa_ahmed15@yahoo.com
}

\section{ISLAMIC ACCOUNTING POLICY CHOICE}

Shariah governs every aspect of a Muslim's life, be it politics, economics or social (Segrado, 2005). It brings the whole of human life under the jurisdiction of absolute moral judgment because of its firm in the revelation of Allah (Haniffa, Hudaib, \& Mirza, 2004; Manzoor, 1984). Such a holistic and unified view provides a better approach in addressing accounting and reporting policies to be adopted by Muslim managers as it takes into account the material, moral and spiritual aspects and balances between these factors and forces (Shafii, \& Zakaria, 2013). The substantiation of their proposed corporate financial reporting model would be greatly enhanced if what Muslims ought to desire is consistent with what Muslims would desire or what Muslims would use for investment decision-making purposes (Sulaiman, 2001). If the Muslims view and use corporate financial reporting information in the manner as propagated by Islam a significant differences will emerge between the responses of Muslim and non-Muslim subjects (Abidin, \& Saad, 2014; Sulaiman, 2001).

The principles of Shariah based on the concept of Uqud to accounting policy choice (Haniffa et al., 2004). A firm can be viewed as a relation of contracts; that is, its organization can be largely described by the set of contracts it enters into (Mirza, \& Baydoun, 1999). Contractual relations are the essence of firms, not only with employees but also with suppliers, customers, creditors and other parties (Islamiyah, Ridho, \& Muslih, 2015). The general assumption in accounting is that firms are likely to minimize the costs associated with 
contracts, such as costs of negotiation, monitoring, possible renegotiation, and expected costs of bankruptcy or other failures (Yaya, \& Hameed, 2004). A consideration of contracting costs drives the firms' accounting and reporting policies. In other words, firms will weigh the cost and benefit of adopting particular accounting and reporting policies.

Firms in an Islamic society are no different from their Western counterparts (Sulaiman, 2003). They also recognize the nexus of contractual relationship in business activities. They are required consider contractual relations beyond own self and fellow beings to include Allah and the environment based on their transaction with Allah, which is to adhere to Shariah as such, measurement and disclosure issues and the firms' choice of accounting and reporting policies must be addressed in the light of contractual relationships that exist within the guidelines, prescribed by Shariah (Rahman, \& Bukair, 2013).

To demonstrate responsibility and accountability to Allah, community and the environment, Muslim managers must to provide excellent lawful products/service to society, earn reasonable profits, attain the objectives of the business venture, be just with employees by paying fair wages and taking care of their welfare, be lenient with debtors, ensure that business activities are ecologically sustainable and recognize work as a form of worship (Haniffa et al., 2004). On the other hand, to demonstrate transparency in business activities, Muslim managers must provide relevant and reliable information regarding all lawful and unlawful activities undertaken, the reasons for undertaking the latter activities and how they are dealt with policies related to financing, investment and employees, relationships with communities, debtors and creditors, the use of resources and protection of the environment (Ammani et al., 2014).

\section{BASIC VALUATION IN ISLAMIC ECONOMIC SYSTEM}

For Islam followers, one of their main principles in economic system is the principle of God "as owner of wealth" (Ibrahim, Wirman, Alrazi, Nor, \& Pramono, 2004). This is the preaching in Islam, which implies that God is the ultimate owner of wealth and people are just trustees. As such, the ownership of property by an individual is a trust (Amanah). This produces a new concept of accountability that is not well known within the western system. This concept is much boarder than the concept of private accountability, which is a new format of accountability that can only be discharged in accordance with Shariah rules (Hameed, Ibrahim, \& Rizal, 2005). The Shariah lays down the understanding and way of achieving accountability. The understanding presented is that people are individually accountable for their actions with what have been entrusted unto them on the final day of judgement (Quran 6: 165; $57: 7)$. The implication is that such a meaning presented another view on the valuation of things and deeds as compared with what is inbuilt in the conventional accounting systems and financial statement (Siddiqi, 1981, Baydoun and Willett, 1997).

Establishing relationship with God in Islam is guided by the concept of Tawheed, which means unity of being one with God (Rahman, 2010). The implication of this concept is a total commitment to the will of Allah. Another emphasis presented by this preaching is the role of individuals in a wide social context and the obligation that these individuals have as not to benefit at the expense of other people (Johari, Ali, AbAziz, \& Ahmad, 2014). All business dealings must be legitimate, and justifiable and far and achieve reasonable amount of profit. While profit is acceptable, excess profit is considered to be the same as exploitation. This is a direct contradiction with conventional accounting the system in businesses, where high level of profit is viewed as an indication of efficiency in the use of resources.

In Islam, preference is given to satisfying communal needs instead of individual needs (Sulaiman, 2003). Whenever the needs of the general public (Ummah) is conflicting with that of individuals, the needs of the general public must prevail. However, the implication here is not that individuals should not put effort to attain their own treatment and cannot be rich. Becoming rich in Islam accepted so long as the wealth is achieved in compliance with the principles of Shariah.

Commerce has a high level of recognition and value in Islam (Lieber, 1968, p. 230). God says that 'Oh you who believe! . . . let there be amongst you traffic and trade by mutual goodwill' (an-Nisa 4: 33). The Prophet Muhammad (Peace Be Upon Him) referred to the honour bestowed upon traders by saying, 'The truthful, honest merchant is with the prophets and the truthful ones and martyrs in the hereafter' (Tirmidhi 12: 4) and 'You ought to be engaged in commerce because ninety-nine per cent of the bounties of God are contained therein' (Mansor, 1984, p. 11). Figure 1 below show valuation in Islamic view: 


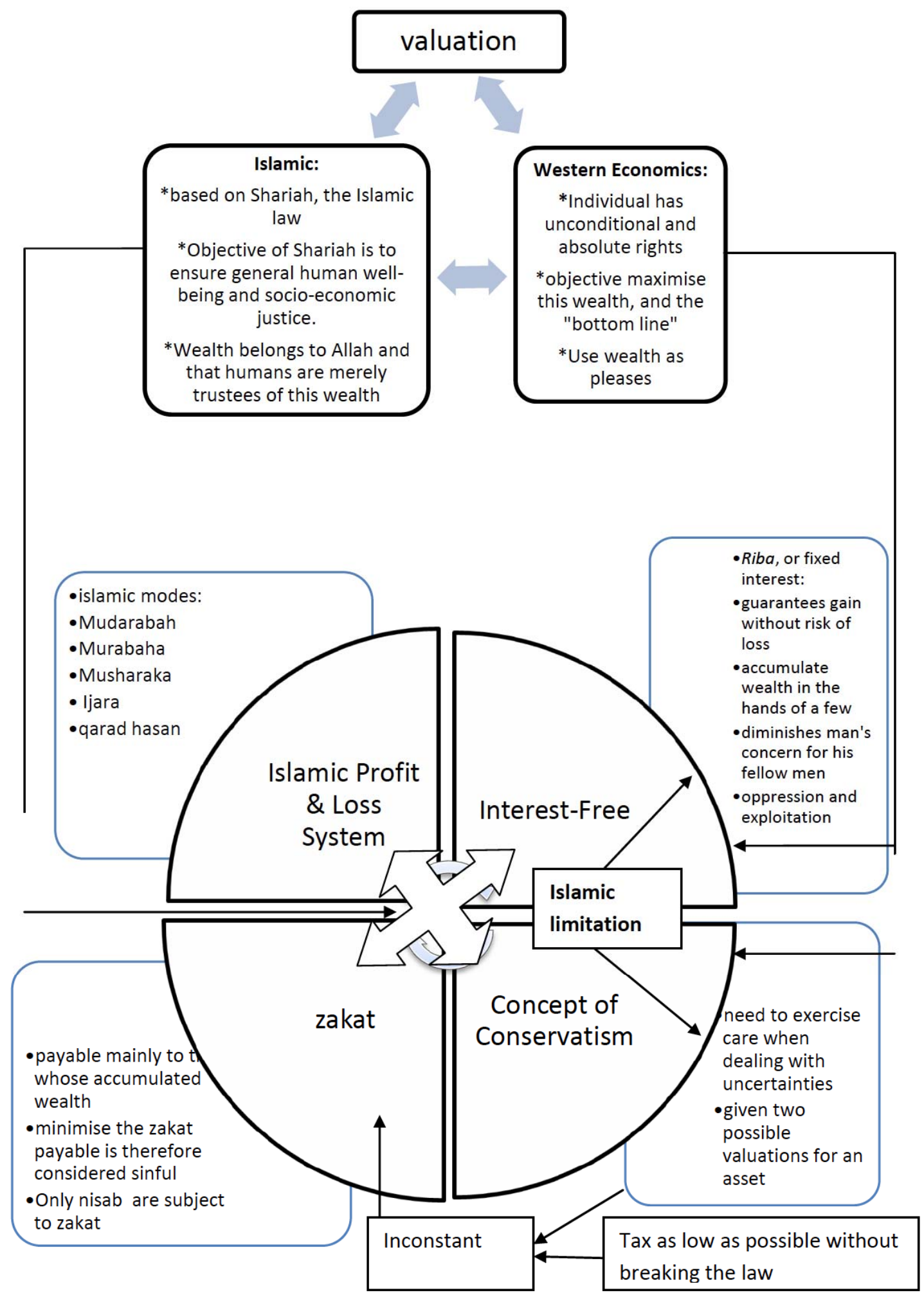

Figure 1: Valuation in Shariah.

\section{ZAKAT RECOGNITION AND MEASUREMENT}

Zakat accounting has been defined as a branch of accounting, which is concerned with determination and valuation of wealth (maal) and income (Ibrahim,
Abdullah, Kadir, \& AdwamWafa, 2012). It measures the amount of Zakat and its distribution to the different beneficiaries according to the rules set by the Shariah. Hence Zakat accounting extends beyond the basic process of measurement and valuation (Hameed, 
2010). It includes accounting principles that relate not only to measurement and valuation but also recording, interpreting, presentation and disclosure of accounting information (Bakar, 2007). In this respect it requires a careful analysis of those accounting concepts and principles which are relevant to the determination, collection and distribution of Zakat.

Furthermore, these concepts and principles require a framework within which their relationships and degree of importance can be established. The formulation of such a framework could not be established unless the legal maxims, rules and applications of figh al-zakat are considered (Ibrahim, Kadir, Rizuan, \& Abdullah, 2013). Zakat rates for each category of wealth depend on traditional classification of Zakat able wealth. A stock-and-flow analysis method is then adapted to categories the actual or potential growth of the business wealth. From this analysis, taxonomy of Zakat able business wealth is suggested that takes into consideration the functional traits of wealth (Embong, Taha, \& Nor, 2013). Important of growth and the relevance of stock and flow analysis. A framework is suggested to develop Zakat recognition and measurement principles for business wealth.

Figure 2 Zakat recognition begins with existence and legitimate ownership of wealth. Its measurement depending on the stock or flow growth process of the economic activity would appropriately use a periodic basis (hawl) or critical event occurrence (Bakar, 2008). A minimum threshold balance (nisaab) is determined from physical measures (or its derived value) after taking into consideration personal consumption or needs (Awang, \& Mokhtar, 2012). Actual or potential growth of wealth is the realized or realizable value that provides motivation to recognize and measure Zakat and distribute accordingly.

According to shariah, Zakat is calculated based on the accumulated wealth (Awang, \& Mokhtar, 2011). The basic principle of Zakat on business wealth is based on trade goods, which means anything obtained for the purpose of trading for profit Abdul Rahim, (2002a). Any assets owned and used in the business operations but not for trade, are exempted from the calculation of 'wealth'. In summary, Zakat on business wealth is payable on genuinely owned wealth, productive and surplus assets that have been owned for a full year Clarke, Craig and Hamid, (1996). 'Genuinely' owned in this context means that the asset is free of claims by others, for example leased assets. Productive assets refer to the ability to generate revenue to the company excluding assets not for trading purposes, that is, buildings occupied by other businesses. The Zakat rate is $2.5 \%$ for companies using the Gregorian calendar year.

\section{VALUATION IN ISLAMIC ACCOUNTING}

Islamic Firms have differences objectives and principles as compared to conventional counterpart (Haliding, 2015). Therefore, Islamic Firms come up with specifically accounting for shariah-compliant companies. For instance, accounting for Islamic financial institutions with regard to Zakat, mudahrabah,

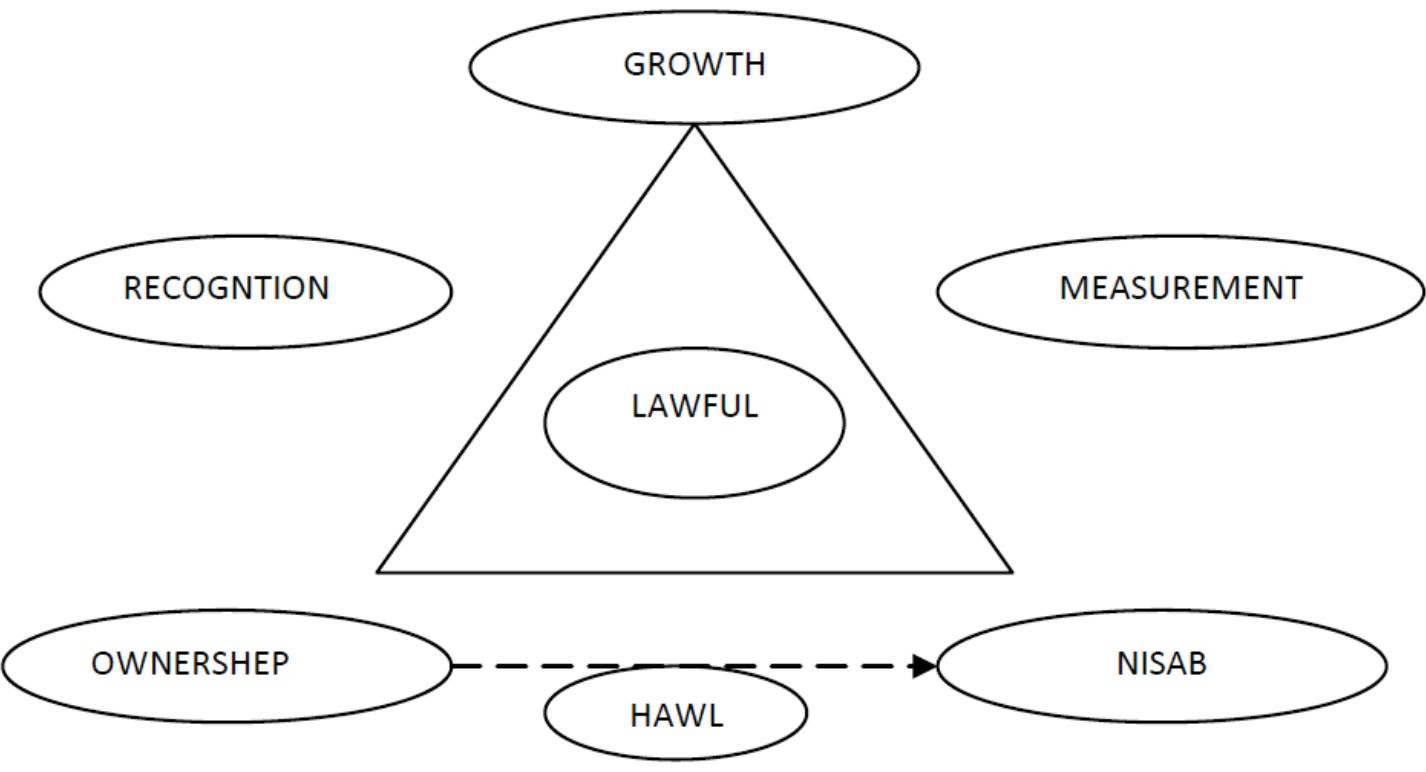

Figure 2: Essential conditions for Zakat recognition and measurement. 
ijarah, murabahah and other Islamic transections and contracts. However, Yaya (2004) argues that in terms of Islamic Accounting's objectives of The AAOIFI, the contents and goals are likely the same with currently conventional accounting that focus on providing information system for users. Accounting exist in the society as a reflection of the business practices that are in that society, and it has little use in terms of value as well (Zaid, 2004). As such, it has to be noted that accounting and valuation practices of firms in the Islamic setting are also likely to present a reflection of shariah transections contracts and business activities practices.

Numerous Islamic nations (e.g. Malaysia, Pakistan, Saudi Arabia, and Brunei) across the globe function in accordance with Islamic code in a number of areas in both their human and business lives. The need for developing standards in accounting and valuation has become an urgent affair for firms in Islamic society as the Islamic world fight strongly in order to revive the Islamic ideology (Bakar, 2007). Additionally, if there is a general agreed standard, then the overall bookkeeping of Islamic firms will greatly be minimized as such standards can easily be integrated into accounting and valuation practices in order to fit the organization's choice instead of adopting standards that frequently require changes as the organization transforms from on phase to another (Ibrahim et al., 2012). Recent studies have also shown that there is a new growing concern with relation to understanding the relationship between religion and accounting, with particular reference to the issue of what the proper form of Islamic accounting is all about (Sulaiman, 2003). The emphasis laid down by these studies is the need to develop set of standard for Islamic accounting and reporting.

From an Islamic viewpoint, the measurement of asset in determination of the amount of Zakat to be issues out is an important issue in the Islamic society (Ismail et al., 2015). In order to calculate the amount of zakat, assets need to be measured in present terms and not in its historical state. For the sake of zakat, firms need to be encouraged to undertake revaluation of their major assets occasionally. Thus, an Islamic accounting system will likely adopt both historical cost and market selling prices. The double system in asset valuation will likely enhance the firm's ability to accommodate contracts and to discharge their social obligations (Haniffa et al., 2004). these policies is that accounting and valuation under the Islamic setting is likely to be more detailed than what is obtainable from conventional accounting practices as such record will put into considerations all elements geared towards elaborating the performance of the company and limiting the potential of investors being put through wrong or misleading information that might influence their investment decisions. All these factors round up towards obeying the will of God and abiding by the Islamic preaching.

\section{ACCOUNTING VALUATION MODEL FOR ZAKAT}

An important contract between human and Allah is the payment of Zakat, one of the five pillars of Islam (Awang et al., 2011). Zakat is important because it is related to wealth distribution. It is a special form of Islamic taxation and a form of worship. Uthman (1997) outlines some major features that the Zakat system avoids inremtaxes, since taxes are imposed on assetholders (persons), not on the activities or objects as such the Zakat system is more in line with the ability to pay theory of taxation. Since each type of wealth has its own treatment in terms of Zakat in Islam, it can be said that people who hold the same type of wealth shall receive the same tax treatment (Haniffa et al., 2004). This provides for horizontal equity. Also, those who have more shall pay more. This provides for vertical equity. It may be more appropriate to look at taxation in Islam (that is proportional) as more in line with the idea of equal proportional vertical sacrifice. Under normal circumstances, individuals are treated individually. The index of the ability to pay is neither income nor consumption. Instead, it is the inventory stock of what can be consumed (but is not) or what is intended to be traded (but is not), or what can be spent (but is not)" (Usmani, 2010). Islamic perspective of accounting encourages valuation method that will increase Zakat payment above the threshold by the Hadith (Hameed, 2005). Valuation of assets is relevant to Zakat as its computing is based on assets, Rather than income (Awang et al., 2012). As far as stewardship is concerned, historical cost is preferred method of valuation. The use of net present values and net realizable values for evaluating stewardship is fraught with theoretical problems.

Several previous studies argued that the accounting measurement contribution to Islamic Financial Institutions refers to the valuation of Zakat (like: Haliding, 2015; Majid, \& Haliding, 2014; Haniffa, \& Hudaib, 2014; Awang et al., 2012; Ahmed, 1994; Adnan and Graffikin, 1997; Mirza and Baydoun, 2000; lewis, 2001; Abdul Rahman, 2003; Yaya, 2004; Lewis, 2006). Furthermore, Yaya (2004) showed that in accounting, Islamic accountability is crucial and Zakat 
as a major objective in Islamic accounting field. His opinion in line with Adnan and Graffikin (1997); Lewis (2006) and Abdul Rahman (2007; 2010).

Related to this viewpoint, Mirza and Baydoun (2000) show that the assets measurement regarding Zakat is important matter from Islamic viewpoint. Thus, according to Mirza and Baydoun (2000) to measure the amount of Zakat, require to utilize the contemporary time rather than historical cost. Mirza and Baydoun (2000) recommend that re-value the assets regularly is required and Islamic accounting system most likely uses both market selling prices and historical with regard to make firms to accommodate contracts and to discharge with social responsibility (SR). Moreover, Adnan and Gaffikin (1997) show as also mentioned by Yaya (2004) believe that is no room in Islamic financial institutions to be used in the concept of conservatism and historical cost because the matters in misleading and justice quality and frankness of financial information.

Abdul Rahman (2007) showed that to have fair Zakat measurement paid by Jamaluddin Majid: The Critical feature on Fair Value Accounting 299 Corporation is one main matter like Zakat for business wealth. Furthermore, Abdul Rahman (2007) argues that business wealth must be paid the Zakat including in business events that involves for example trade goods, cash at bank or in hand, credit or debit extended to customers or other events.

According to Zakat, Abdul Rahman's study (2007) argued that in Malaysia context in matter of Zakat, IFls must reports: 1) The Zakat amount due or paid; 2) The measurement method of Zakat; 3) the rule of Shariah supervisory board regarding Zakat; and 4) The commitment on Zakat due as of the equity investment account, the subsidiaries, and other investment account (in Islamic banks cases). In addition,, Abdul Rahman (2007) demonstrates that there is a lack of providing information about Zakat practices which is the users of annual reports need.

It is worth mentioning that related to Zakat that presented by AAOIFI in FAS no.9, discussing matters in standard accounting treatment of Zakat disclosure and base requirement. According to determination of Zakat AAOIFI FAS no. 9. Para.2, "the Zakat base shall be determined by using $2.5 \%$ for a lunar calendar year and $2.5775 \%$ for a solar calendar year based on either of the following two methods: Net Assets, Net Invested Funds". In addition, Zakat must be measured at cash equivalent value as recommended by AAOIFI FAS no.9. para. 5. Yet, Abdul Rahman (2007) admitted that AAOIFI under FAS no.9 did not offer the exact regarding to charge the net receivables.

Besides, regarding the treatment of Zakat in financial statements FAS no.9.para. 9 AAOIFI: case in which the Islamic banks are compelled to pay Zakat: "In any of the following cases, Zakat would be treated as a (non-operating) expense of the Islamic bank and would be included in the determination of the income statement:

(a). When the law require the Islamic bank to satisfy the Zakat obligation. (b). When the Islamic bank is required by its charter or by-law to satisfy the Zakat obligation. (c). When the general assembly of shareholders has passed a resolution requiring the Islamic bank to satisfy the Zakat obligation.

Abdul Rahman (2007) showed that matters in fairness in Zakat are very vital like providing justice to both Zakat recipient and Zakat payer respectively. Wahab and Abdul Rahman (2011) stated that because distribution of Zakat funds that there are several shortcoming and weakness that significantly influence payment to Zakat institutions. Thus, Islamic accountability on accounting is vital as well as 300 Allqtishad: Vol. VI No. 2, Juli 2014 transparency in Islamic financial Institutions. Furthermore, Abdul Rahman (2007) shows that in Islamic viewpoint the preparation of financial information need to be taken in account to Zakat purpose.

The valuation of assets for determining the amount of Zakat is an important issue. Uthman (1997) lists six general requisite conditions for Zakat to be collected: absolute ownership, accretion, Nisa'b (or some minimum level of wealth stock) that differ from one type of wealth to another, excess over ones basic needs, a solvency from debt, and the elapsing of one lunar year of the stock to be taxed. To calculate the amount of Zakat, assets need to be valued in As such; firms need to adopt a policy of revaluing their major assets occasionally. In conventional accounting, an amount of doubtful debts is deducted from the gross amount of accounts receivable. However, for computation of Zakat, only the actual amount of debts that have gone bad needs to be deducted. In the case of insolvency, owners of the business are not ab1e for Zakat if creditors remain unpaid. Valuation of asset for Zakat purposes should follow the periodicity i.e. one full lunar year of asset except for agriculture and mining where 
Zakat must be paid immediately. In short, the choice of accounting policy for Zakatis entirely different from the choice in typical Western business where accounting policy choice is aimed at minimizing tax, that is, taking actions to In Islam, the policy is aimed at purifying and contributing to the well-being of the beneficiaries to achieve socioeconomic justice.

Therefore, for determination and payment of Zakat, asset valuation needs to be based on current values. It is interesting to note that an earlier version of the Draft Statement of Concepts of Financial Accounting for Islamic Banks and Financial Institutions suggested the use of the "cash equivalent value" expected to be realized or paid as the attribute of assets and liabilities in the financial statements. The cash equivalent value expected to be paid is the number of monetary units required, as of the current date, to acquire a specific quantity of certain goods or products to settle a forward delivery or manufacturing obligation (Karim, 1995). Zakat is calculated on the value of assets in contemporaneous time; the only relevant value of asset on which Zakat is paid, therefore, is current cash equivalent (market price).

\section{CONCLUSION}

Accounting and valuation of zakat has been described earlier as a necessary instrument in understanding the performance of a firm and the potential for shariah-compliant. The accounting and valuation are done in line with Islamic preaching which is basically against interest based transactions and the prediction of future. It will be stated that the Islamic accounting and valuation model adopted in Islamic firms is centred on understanding the best approaches to be adopted in order to ensure that valuation assets for zakat payment are in line with the Shariah principles. Valuation of asset for Zakat purposes should follow the periodicity i.e. one full lunar year of asset except for agriculture and mining where Zakat must be paid immediately. In short, the choice of accounting policy for Zakat is entirely different from the choice in typical Western business where accounting policy choice is aimed at minimizing tax, that is, taking actions to In Islam, the policy is aimed at purifying and contributing to the well-being of the beneficiaries to achieve socioeconomic justice.

\section{REFERENCES}

Abdul Rahim. A, R. 2002a. Zakat on business wealth in Malaysia: Corporate tax rebate, accountability and governance. Zakat Accounting Conference.
Abidin, S \& Saad, R (2014) Evaluating Corporate Reporting on the Internet: The Case of Zakat Institutions in Malaysia. Jurnal Pengurusan 42(2014) $19-29$ http://dx.doi.org/10.17576/pengurusan-2014-42-03

Abdullah, A., \& Muhammad, J. (2013). Ethical values in Islamic financial planning. Jurnal Pengurusan (UKM Journal of Management), 38

Accounting Standards Steering Committee. 1975. The Corporate Report. London.

Al-Gaoud, L. M. and M. K. Lewis. 1997. The Bahrain Financial Centre: Its present and future role in Islamic financing. Accounting, Commerce \& Finance: The Islamic Perspective. 1, No. 2: 43-66.

Ahmad, W., \& Marhaini, W. (2012). Zakat investment in Malaysia: a study of contemporary policy and practice in relation to Shari'a.

Ammani, S. A., Abba, S. A., \& Dandago, K. I. (2014). Zakah on employment income in Muslims majority states of Nigeria: Any cause for alarm?.Procedia-Social and Behavioral Sciences, 164, 305-314. http://dx.doi.org/10.1016/j.sbspro.2014.11.081

Awang, R., \& Mokhtar, M. Z. (2011). Technical Comparison between Business Zakat and Tax on Business Income in Malaysia. Malaysian Accounting Review, 10(2), 13-25.

Awang, R. N., \& Mokhtar, M. Z. (2012). Comparative Analysis of Current Values and Historical Cost in Business Zakat Assessment: An Evidence from Malaysia. International Journal of Business and Social Science, 3(7).

Bakar, N. B. A. (2007). A zakat accounting standard (ZAS) for Malaysian companies. American Journal of Islamic Social Sciences, 24(4), 74.

Bakar, N. B. A. (2008). Zakat and Taxation: A conceptual Comparison.TAFHIM: IKIM Journal of Islam and the Contemporary World, 2(3).

Ball, R. 1988. "The firm as a specialist contracting intermediary: Application to accounting and auditing". Unpublished manuscript. University of Rochester.

Baydoun, N. and R. Willett. 1997. Islam and accounting: Ethical issues in the presentation of financial information. Accounting, commerce \& Finance: The Islamic Perspective. Vol.1, No.1 [June]: 1-25.

Chambers, R. J. 1966. Accounting, Evaluation, and Economic Behavior. Englewood Cliffs, N.J.: Prentice-Hall.

Clarke, F, R. Craig and S, Hamid. 1996. Physical assets valuation and Zakat: Insights and implication. Advance in International Accounting 9.

Coase, R. 1937. The nature of the firm. Economica. 4 [November]: 386-405. http://dx.doi.org/10.1111/j.1468-0335.1937.tb00002.x

Embong, M. R., Taha, R., \& Nor, M. N. M. (2013). Role of zakat to eradicate poverty in Malaysia. Jurnal Pengurusan (UKM Journal of Management), 39.

Firdaus, M., Beik, I. S., Irawan, T., \& Juanda, B. (2012). Economic estimation and determinations of Zakat potential in Indonesia. Jeddah: Islamic Research and Training Institute.

Frankel, R., M. McNichols, and G. P. Wilson. 1995. Discretionary disclosure and external financing. The Accounting Review. 70 [January]: 135-150.

Gambling, T. E. and R. A. A. Karim. 1986. Islam and 'Social accounting'. Journal of Business Finance \& Accounting. 13 (1): $39-50$. http://dx.doi.org/10.1111/j.1468-5957.1986.tb01171.x

Gambling, T. E. and R. A. A. Karim. 1991. Business and Accounting, Ethics in Islam. London: Mansell Publishing Co.).

Gray, R., D. Owen, and K. Maunders. 1987. Corporate social reporting: Accounting and accountability. Prentice-Hall International. 
Haliding, S. (2015). The Critical Aspect on Fair Value Accounting and its Implication to Islamic Financial Institutions. Global Review of Islamic Economics and Business, 1(3).

Hameed, S., Ibrahim, M., \& Rizal, Y. (2005). The emerging issues on the objectives and characteristics of Islamic accounting for Islamic business organizations.

Hameed, S. (2010). Islamic Accounting-A Primer. Akauntan Nasional (Currently Accountants Today) Jan-Feb, (2003), 93.

Hamid, S.; R. Craig and F. Clarke. 1993. Religion: A confounding cultural element in the international harmonisation of accounting? ABACUS. 29, No. 2: 131-148. http://dx.doi.org/10.1111/j.1467-6281.1993.tb00427.x

Haniffa, R., \& Hudaib, M. (2014). 12. The Islamic accounting triangle: measurement, disclosure and enforcement. Handbook on Islam and Economic Life, 227.

Haniffa, R., Hudaib, M., \& Mirza, A. M. (2004). Accounting Policy Choice within the Shariah Islamiiah Framework. Discussion Papers In Accountancy And Finance, SOBE, University Of Exeter, 2, 4-19.

Healy, P. M. and K. G. Palepu. 1993. The effect of firms' financial disclosure strategies on stock prices. Accounting Horizons. 7 [March]: 1-11.

Healy, P.; K. Palepu; and A. Sweeney. 1995. Causes and consequences of expanded voluntary disclosure. [June]: Unpublished paper, MIT Sloan School of Management.

Hussein, H. S. 1986. Financial intermediation in the framework of Shariah. IDB - IRTI Seminar on Developing a System of Islamic Financial Instruments.

Ibrahim, S. H. M., Wirman, A., Alrazi, B., Nor, M. N. B. M., \& Pramono, S. (2004, April). Alternative Disclosure \& Performance Measures For Islamic Banks. In Second Conference on Administrative Sciences: Meeting the Challenges of the Globalization Age, King Fahd University of Petroleum \& Minerals, Dhahran, Saudi Arabia (pp. 19-21).

Ibrahim, A., Abdullah, A. A., Kadir, M. R. B. A., \& AdwamWafa, S. M. G. W. S. (2012). Assessing Financial Reporting on adopting Business Zakat Guidelines on Malaysian Government Linked Companies. International Journal of Business and Social Science, 3(24).

Islamiyah, N., Ridho, A. F., \& Muslih, M. R. (2015) Optimizing the Role of Accounting through the Statement of Value Added Approach to Increase the Transparency of Reporting Islamic Financial Institutions in Indonesia

Ismail, A. G., Tohirin, A., \& Ahmad, M. A. J. (2015). Debate on Policy Issues in the Field of Zakat on Islamic Bank Business (No. 1435-3). The Islamic Research and Teaching Institute (IRTI).

Ibrahim, A., Kadir, A., Rizuan, M., \& Abdullah, A. A. (2013). Perception of Accounting Practitioners on MASB TRi. International Journal of Humanities and Social Science, 3(2), 1-7.

Jensen, M. C. and W. H. Meckling. 1976. Theory of the firm: Managerial behaviour, agency costs and ownership structure. Journal of Financial Economics. 3 [October]: 30560.

http://dx.doi.org/10.1016/0304-405X(76)90026-X

Johari, F., Ali, A. F. M., AbAziz, M. R., \& Ahmad, N. (2014). The Importance of Zakat Distribution and Urban-Rural Poverty Incidence among Muallaf (New Convert). Asian Social Science, 10(21), 35. http://dx.doi.org/10.5539/ass.v10n21p42

Karim, R. A. A. 1995. The nature and rationale of a conceptual framework for financial reporting by Islamic banks. Accounting and Business Research. 25, No. 100: 285-300. http://dx.doi.org/10.1080/00014788.1995.9729916

Khan, F. 1986. Discounting for time value: An Islamic perspective. Mimeo, International Institute of Islamic Economics, Islamabad, Pakistan.
Khan, L. A., \& Ramadan, H. M. (2011). Contemporary ijtihad: Limits and controversies. Edinburgh University Press.

Lieber, A.E. 1968. Eastern business practices and medieval commerce. Economic History Review. 21, No. 2. http://dx.doi.org/10.2307/2592433

Littleton, A. C. and V. K. Zimmerman. 1962. Accounting Theory: Continuity and Change. Englewood Cliffs, New Jersey: Prentice-Hall.

Mirza, A. M. 1991. Social reporting and managers' self-interest. Accounting Research Journal. 7-17.

Mirza, M., \& Baydoun, N. (1999). Accounting policy choice in an interest-free environment. In The Islamic Perspective International Conference m in Jakarta, Indonesia (pp. 15-18

Paton, W. and A.C. Littleton. 1940. An Introduction to Corporate Accounting Standards. Florida: American Accounting Association

Rahman, A. R. A. (2010). Introduction to Islamic Accounting Theory and Practice. Cert Publication, Kuala.

Rahman, A. A., \& Bukair, A. A. (2013). The influence of the Shariah supervision board on corporate social responsibility disclosure by Islamic banks of Gulf Co-operation Council countries. Asian Journal of Business and Accounting, 6(2).

Richardson, G. D. 1996. "The striking robustness of theories of voluntary disclosure for explaining corporate disclosure choices in prospectuses, annual reports and other OSC filings". Unpublished paper, University of Waterloo, September, 1996.

Sarif, S. (2014). Income generation through zakat: the Islamization impact on Malaysian religious institution.

Segrado, C. (2005). Case study "Islamic microfinance and socially responsible investments". Italy: MEDA Project

Shafii, Z., \& Zakaria, N. (2013). Adoption of International Financial Reporting Standards and International Accounting Standards in Islamic Financial Institutions from the Practitioners' Viewpoint. Middle-East Journal of Scientific Research (Research in Contemporary Islamic Finance and Wealth Management, 13(1), 42-49

Siddiqi,. M. N. 1981. Muslim Economic Thinking: A survey of contemporary literature. The Islamic Foundation, United Kindgom.

Sprouse, R. T. 1987. The case for financial accounting standards. Accounting Horizons. [June]: 83-86.

Sulaiman, M. (2001). Testing a model of Islamic corporate financial reports: some experimental evidence. International Journal of Economics, Management and Accounting, 9(2).

Sulaiman, M. (2003). The influence of riba and zakat on Islamic accounting. Indonesian Management and Accounting Review, 2(2), 149-167.

Sulaiman, M. (2001). Testing a model of Islamic corporate financia reports: some experimental evidence. International Journal of Economics, Management and Accounting, 9(2).

Talib, A. A., and T. S. Phay. 1998. The Islamic economic system and riba: The foundation of Islamic banking. Accounting, Commerce \& Finance: The Islamic Perspective Journal. 2, No. 3: $51-82$

Tomkins. C. and R. A. A. Karim. 1987. The Shari'ah and its implications for Islamic financial analysis: An opportunity to study interactions among society, organisation, and accounting. American Journal of Islamic Social Sciences. 4, No. 1: 101-115.

Usmani, M. I. A., \& Qazi, B. A. (2010). Guide to Zakah: Understanding and Calculation.

Wartick, S.L. and P.L. Cochran. 1985. The evolution of the corporate social performance model. Academy of Management Review. 10, No. 4. 
Yaya, R., \& Hameed, S. (2004). Objectives and Characteristics of Islamic Accounting: Percepation of Muslim Accounting Academician in Yogyakarta, Indonesia. In International Conference Pan Pacific

Received on 22-02-2016
Zaid, O. A. (2004). Accounting systems and recording procedures in the early Islamic state. The Accounting Historians Journal, 149-170.

DOI: http://dx.doi.org/10.6000/1929-7092.2016.05.02

(C) 2016 Ahmed et al.; Licensee Lifescience Global.

This is an open access article licensed under the terms of the Creative Commons Attribution Non-Commercial License (http://creativecommons.org/licenses/by-nc/3.0/) which permits unrestricted, non-commercial use, distribution and reproduction in any medium, provided the work is properly cited. 